\title{
Heavy Metal Adsorption onto Kappaphycus sp. from Aqueous Solutions: The Use of Error Functions for Validation of Isotherm and Kinetics Models
}

\author{
Md. Sayedur Rahman and Kathiresan V. Sathasivam \\ Faculty of Applied Sciences, AIMST University, 08100 Bedong, Kedah, Malaysia \\ Correspondence should be addressed to Kathiresan V. Sathasivam; kathir.aimst@gmail.com
}

Received 17 March 2015; Revised 29 June 2015; Accepted 30 June 2015

Academic Editor: José L. Campos

Copyright (c) 2015 Md. S. Rahman and K. V. Sathasivam. This is an open access article distributed under the Creative Commons Attribution License, which permits unrestricted use, distribution, and reproduction in any medium, provided the original work is properly cited.

\begin{abstract}
Biosorption process is a promising technology for the removal of heavy metals from industrial wastes and effluents using lowcost and effective biosorbents. In the present study, adsorption of $\mathrm{Pb}^{2+}, \mathrm{Cu}^{2+}, \mathrm{Fe}^{2+}$, and $\mathrm{Zn}^{2+}$ onto dried biomass of red seaweed Kappaphycus sp. was investigated as a function of $\mathrm{pH}$, contact time, initial metal ion concentration, and temperature. The experimental data were evaluated by four isotherm models (Langmuir, Freundlich, Temkin, and Dubinin-Radushkevich) and four kinetic models (pseudo-first-order, pseudo-second-order, Elovich, and intraparticle diffusion models). The adsorption process was feasible, spontaneous, and endothermic in nature. Functional groups in the biomass involved in metal adsorption process were revealed as carboxylic and sulfonic acids and sulfonate by Fourier transform infrared analysis. A total of nine error functions were applied to validate the models. We strongly suggest the analysis of error functions for validating adsorption isotherm and kinetic models using linear methods. The present work shows that the red seaweed Kappaphycus sp. can be used as a potentially low-cost biosorbent for the removal of heavy metal ions from aqueous solutions. Further study is warranted to evaluate its feasibility for the removal of heavy metals from the real environment.
\end{abstract}

\section{Introduction}

Heavy metal pollution due to rapid urbanization and industrialization is one of the most significant environmental problems. Heavy metals are released into the aquatic environment from several domestic (automobile exhaust, smelting processes, burning of fossil fuels, incineration of wastes, landfill leaches, use of sewage sludge, municipal wastewater, and urban runoff) and industrial processes (electroplating, refining ore, mining, electronic and metal-finishing industries, fertilizer industry, tanneries, painting, paper industries, and pesticides) [1]. Heavy metals have become a global issue of environment and public health concern due to their toxicities, bioaccumulation in human body and food chain, carcinogenicities, and mutagenesis in various living organisms [2-4].

Numerous methods such as chemical precipitation, ion exchange, coagulation-flocculation, flotation, membrane filtration, electrochemical treatment, magnetic separation and purification, biosorption, and nanotechnology are being used to treat or remove heavy metals from water and wastewater $[1,5,6]$. Among them, biosorption has been regarded as a promising cost-effective, sustainable, and ecofriendly technology for the removal of different types of organic and inorganic pollutants from water and wastewater [7]. Moreover, this process offers a number of advantages in comparison to the conventional methods [8].

A wide range of commercial and potentially low-cost adsorbents including living or dead microorganisms, seaweeds, plant materials, industrial and agricultural wastes, natural residues, and inorganic precursors including red mud, clays, blast furnace slags, zeolites, chitosan, and peat has been reported in literature [8-12]. Seaweeds are widely distributed in marine, freshwater, and terrestrial ecosystems, which can serve as good biosorbents due to their abundance, cost-effectiveness, reusability, and high metal sorption capacities $[7,10,11]$. Despite that fact that the red algae 
constitute carrageenan that provides different binding sites (e.g., hydroxyl, carboxyl, amino, and sulfhydryl) responsible for the adsorption for heavy metals [9], they are the least focused group [13]. Therefore, further research studies are warranted on the selectivity of algal species [9].

The red seaweed Kappaphycus sp. is one of the most important commercial sources of kappa-carrageenan, which also has different medicinal and industrial applications [14]. Malaysia produced 331,490 tonnes of Kappaphycus sp., being $17.039 \%$ of the total world production in 2012 [15]. Recent studies suggest that both the living biomass and the waste biomass of Kappaphycus alvarezii are a good biosorbent for the removal of nutrients [13] and heavy metals from the aqueous environment $[16,17]$. However, there is no available literature report on the biosorption of heavy metals using the dry biomass of Kappaphycus sp. Hence, the present study was investigated to study the performance of the dried biomass of Kappaphycus sp. for the removal of $\mathrm{Zn}^{2+}, \mathrm{Cu}^{2+}, \mathrm{Pb}^{2+}$, and $\mathrm{Fe}^{2+}$ from aqueous solutions in batch system at laboratory scale under different parameters like $\mathrm{pH}$ of solution, contact time, temperature, and initial metal ion concentrations. The Fourier transform infrared (FTIR) spectral analysis was made to identify the main functional groups involved in the biosorption process of those metal ions.

In general, mechanistic or empirical equations are used to express heavy metal adsorption capacities of different types of biosorbents using batch or column method [18]. Available literature reports confirm that nearly two dozens of empirical models involving 2, 3, 4, or even 5 parameters have been used to fit batch equilibrium isotherm curves to biosorbents $[18,19]$. Besides, kinetic models have been described by several authors elsewhere [20-22]. The equilibrium and kinetic models are often validated on the basis of coefficient of regression $\left(R^{2} \geq 0.99\right)$ of the experimental data. In the present study, some error functions have been used for validating the experimental data along with an insight into the usual measures of model inferences.

\section{Materials and Methods}

2.1. Collection, Identification, and Preparation of the Biosorbent. The red seaweed Kappaphycus sp. was collected from the Semporna coast of Sabah, Malaysia, in April 2013. The alga was washed for several times with running water and subsequently with deionized water to remove epiphytes and salts. The washed biomass was then dried in an oven at $60^{\circ} \mathrm{C}$ for $48 \mathrm{~h}$ until a constant weight was attained. The dried biomass was then crushed with an analytical mill, sieved ( $250 \mu \mathrm{m}$ size), and stored in polypropylene bottles until use.

The living biomass of the species was preliminarily identified following systemic morphological features [23]. It was then subjected to $28 \mathrm{~S}$ DNA based molecular identification [24]. The species was identified as Kappaphycus sp. and the gene sequence of the nucleotide was submitted in the NCBI GenBank (accession number KM229320).

2.2. Chemicals and Reagents. All the chemicals and reagents used in this study were of analytic reagent grade. The working solutions of different concentrations (10-200 $\left.\mathrm{mg} \mathrm{L}^{-1}\right)$ of the heavy metals $(\mathrm{Zn}, \mathrm{Cu}, \mathrm{Pb}$, and $\mathrm{Fe}$ ) were prepared by diluting the stand solutions $\left(1000 \pm 2 \mathrm{mg} \mathrm{L}^{-1}\right)$ of the metals (Merck, Germany) in double distilled deionized water. Different initial $\mathrm{pH}$ of the solutions was obtained by adding $0.1 \mathrm{~N} \mathrm{HCl}$ (Sigma-Aldrich, USA) or $0.1 \mathrm{~N} \mathrm{NaOH}$ (Merck, Germany).

2.3. Batch Biosorption Experiments. All the experiments were conducted in a batch system using $150 \mathrm{~mL}$ Erlenmeyer flasks in a thermostatic shaker $\left(25^{\circ} \mathrm{C}, 180 \mathrm{rpm}\right)$, unless otherwise stated. Each flask was filled with $50 \mathrm{~mL}$ of solution and biosorbent as appropriate. The influence of several operational parameters on the biosorption characteristics of the metals such as $\mathrm{pH}$ of the aqueous solution (2-7), contact time $(0-120 \mathrm{~min})$, initial metal ion concentration $\left(25-200 \mathrm{mg} \mathrm{L}^{-1}\right)$, and temperature $\left(25-50^{\circ} \mathrm{C}\right)$ were assessed using a constant biomass dosage $\left(4 \mathrm{~g} \mathrm{~L}^{-1}\right)$. Competitive adsorption of the four metal ions under mixed condition was also evaluated.

The adsorption studies were conducted with $50 \mathrm{~mL}$ of the metal solutions at an initial concentration of $10 \mathrm{mg} \mathrm{L}^{-1}$. For the kinetic studies sample solutions were withdrawn at regular intervals and the residual concentration of the heavy metals in the aqueous phase was analyzed after filtration as stated above.

The amount of the metal ions remaining in the solutions was measured by using Atomic Absorption Spectrometer (AAnalyst700, Perkin-Elmer, USA) after separation of the biosorbent by filtration through Whatman Filter number 1 .

The amount of metal adsorbed per gram of the biosorbent at equilibrium, $q_{e}\left(\mathrm{mg} \mathrm{g}^{-1}\right)$, was calculated from the difference of the metal concentration in the aqueous phase before and after biosorption as follows:

$$
q_{e}=\frac{\left(C_{0}-C_{e}\right) \times V}{m},
$$

where $C_{0}$ and $C_{e}$ are the initial and equilibrium concentration of metal ions in the solution $(\mathrm{mg} / \mathrm{L})$, respectively, $V$ is the volume of metal solution (L), and $m$ is the mass of the dry biosorbent (g).

The percentage of metal removal $(R, \%)$ from the solution was calculated as follows:

$$
R(\%)=\frac{\left(C_{0}-C_{e}\right) \times 100}{C_{0}} .
$$

Each experiment was done in triplicate and the data were expressed as the mean of the triplicate results. Statistical analyses were performed using Microsoft Office Excel 2007 (Microsoft Corp., USA).

2.4. Application of Adsorption Models. In the present experiment, four two-parameter isotherm models: Langmuir, Freundlich, Temkin, and Dubinin-Radushkevich (D-R); four two-parameter kinetic models: pseudo-first-order (PFO), pseudo-second-order (PSO), Elovich, and intraparticle diffusion (IpD); and kinetic model were applied to describe the sorption behaviour of the adsorbent. The equations of these models are given in Table 1. 
TABLE 1: Equations of the isotherm, kinetic, and thermodynamic models used in the study.



$\overline{C_{0}\left(\mathrm{mg} \mathrm{L}^{-1}\right) \text { : adsorbate initial concentration, } C_{e}\left(\mathrm{mg} \mathrm{L}^{-1}\right) \text { : adsorbate equilib- }}$ rium concentration, $q_{e}\left(\mathrm{mg} \mathrm{g}^{-1}\right)$ : observed biosorption capacity at equilibrium, $q_{m}\left(\mathrm{mgg}^{-1}\right)$ : maximum biosorption capacity, $K_{L}\left(\mathrm{~L} \mathrm{mg}^{-1}\right)$ : Langmuir constant related to the energy of adsorption, $\left(R_{L}\right)$ : a dimensionless constant, known as separation factor, $K_{F}\left(\mathrm{mgg}^{-1}\right)\left(\mathrm{L} \mathrm{mg}^{-1}\right)^{1 / n}$ : Freundlich isotherm constant related to the sorption capacity, $n$ : a constant which gives an idea of the grade of heterogeneity, $R\left(8.314 \mathrm{~J} \mathrm{mo}^{-1}\right)$ : universal gas constant, $T\left({ }^{\circ} \mathrm{K}\right)$ : absolute temperature, $A_{T}\left(\mathrm{~L} \mathrm{mg}^{-1}\right)$ : equilibrium binding constant corresponding to the maximum binding energy, $b_{T}\left(\mathrm{~J} \mathrm{~mol}^{-1}\right)$ : Temkin constant related to heat of sorption, $B_{D}\left(\mathrm{~mol}^{2} \mathrm{~kJ}^{-2}\right)$ : Dubinin-Radushkevich isotherm constant, $\varepsilon$ : Polanyi potential related to the equilibrium concentration, $E\left(\mathrm{~kJ} \mathrm{~mol}^{-1}\right)$ : mean free energy of biosorption, $q_{t}\left(\mathrm{mg} \mathrm{g}^{-1}\right)$ : equilibrium adsorption uptake at time, $t, k_{1}\left(\mathrm{~min}^{-1}\right)$ : pseudo-first-order rate constant of adsorption, $k_{2}\left(\mathrm{~g} \mathrm{mg}^{-1} \mathrm{~min}^{-1}\right)$ : pseudo-second-order rate constant of adsorption, $h\left(\mathrm{mg} \mathrm{g}^{-1} \mathrm{~min}^{-1}\right)$ : initial adsorption rate, $t_{1 / 2}(\mathrm{~min})$ : half-adsorption time, $\alpha\left(\mathrm{mg} \mathrm{g}^{-1} \mathrm{~min}^{-1}\right)$ : initial adsorption rate constant, $\beta$ $\left(\mathrm{g} \mathrm{mg}^{-1}\right)$ : desorption constant, $C\left(\mathrm{mg} \mathrm{g}^{-1}\right)$ : boundary layer diffusion effect, $k_{d}\left(\mathrm{mg} \mathrm{g}^{-1} \mathrm{~min}^{-0.5}\right)$ : rate constant for intraparticle diffusion, $\Delta G^{\circ}\left(\mathrm{kJ} \mathrm{mol}^{-1}\right)$ : change in Gibbs free energy, $\Delta H^{\circ}\left(\mathrm{kJ} \mathrm{mol}^{-1}\right)$ : change in enthalpy, $\Delta S^{\circ}$ $\left(\mathrm{kJ} \mathrm{mol}^{-1} \mathrm{~K}^{-1}\right)$ : change in entropy, and $K_{\mathrm{eq}}$ : thermodynamic equilibrium constant.

2.5. Error Function Analysis. In order to evaluate the suitability of the equation to the experimental data error function is the best optimization procedure. Apart from the regression coefficient $\left(R^{2}\right)$, nine error functions such as sum of square error $(S S E)$, average relative error $(A R E)$, hybrid functional error (HYBRID), sum of absolute error (EABS), Marquardt's percent standard deviation (MPSD), normalized standard deviation $(\Delta q(\%))$, coefficient of determination $\left(r^{2}\right)$, nonlinear chi-square test $\left(\chi^{2}\right)$, and residual root mean square error (RMSE) were calculated to evaluate the best fit of the modeled equation to the experimental data. The equations of the error functions are given in Table 2.

2.6. FTIR Analysis. FTIR spectral analysis was carried out to determine the possible functional groups present in the dried biomass of Kappaphycus sp. Infrared spectra of the raw and metal-loaded biomass were obtained using a Fourier transform infrared (FTIR) spectrometer (Spectrum GX, PerkinElmer, USA).

\section{Results and Discussion}

3.1. Effect of Solution $p H$. In the adsorption process of metal ions from aqueous solutions, $\mathrm{pH}$ of the solution plays an important role. It is apparent from the results represented graphically in Figure 1(a) that, with the increase in $\mathrm{pH}$, the biosorption increased gradually. The maximum biosorption (54.13\%, 81.84\%, 84.17\%, and 20.94\% for $\mathrm{Zn}^{2+}, \mathrm{Cu}^{2+}, \mathrm{Pb}^{2+}$, and $\mathrm{Fe}^{2+}$, resp.) was observed at $\mathrm{pH}$ 5. At lower $\mathrm{pH}(2-$ 4 ), biosorption of metal ions was inhibited greatly. This can be explained on the basis that cell wall of the Карраphycus sp. contains various functional groups (as described in Section 3.9). The positively charged functional groups increase competition between protons and metal cations for binding active sites of biomass, resulting in decreasing the metal cations adsorption on the biomass surfaces [48]. At higher $\mathrm{pH}$ values (6-8), the biosorption efficiency of metal ions was significantly decreased (Figure 1(a)), which may be attributed to the formation of anionic hydroxide complexes that decrease the dissolved metal concentration in solution and their competition with the active sites [49]. Therefore, all the rest biosorption experiments were carried out at $\mathrm{pH} 5$.

3.2. Effect of Contact Time. As shown in Figure 1(b), biosorption of metal ions on the adsorbent increased with an increase in contact time and the equilibrium biosorption was attained within 90-120 min reflecting rapid initial biosorption. Maximum uptake of $\mathrm{Cu}^{2+}, \mathrm{Pb}^{2+}, \mathrm{Fe}^{2+}$, and $\mathrm{Zn}^{2+}$ was reached up to $83.88,85.89,21.27$, and $54.13 \%$, respectively, within $90 \mathrm{~min}$. A decrease in the biosorption was noticed during the subsequent time of incubation indicating the maximum adsorption level as a saturation point of biosorption. The rapid kinetic mechanism can be attributed to the formation of exterior surface complexes neglecting intraparticle diffusion, which is very advantageous in biotechnological processes for wastewater treatment [48]. In general, heavy metal biosorption efficiency of seaweeds attained a maximum level within 30 and $90 \mathrm{~min}$ [50]. Hence, a contact time of $120 \mathrm{~min}$ was selected for further experiments ensuring attainment of equilibrium conditions. 


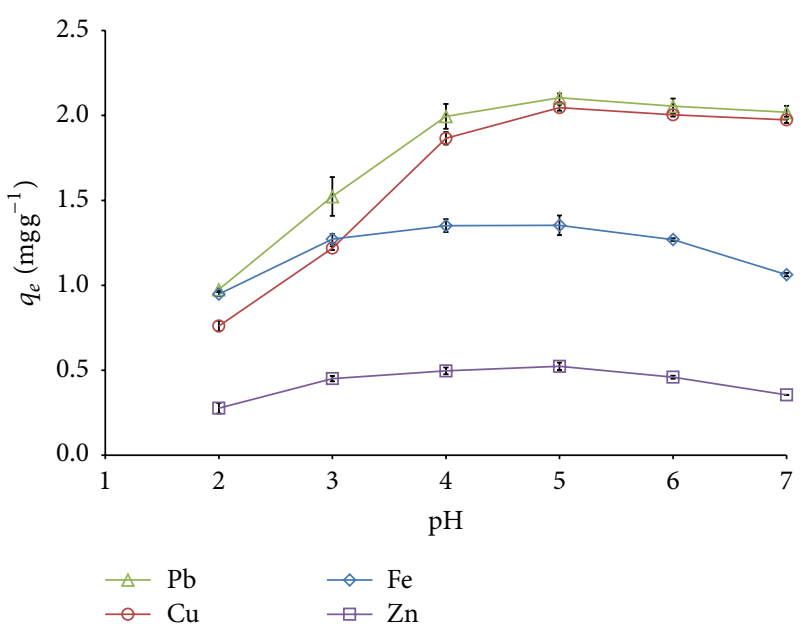

(a)

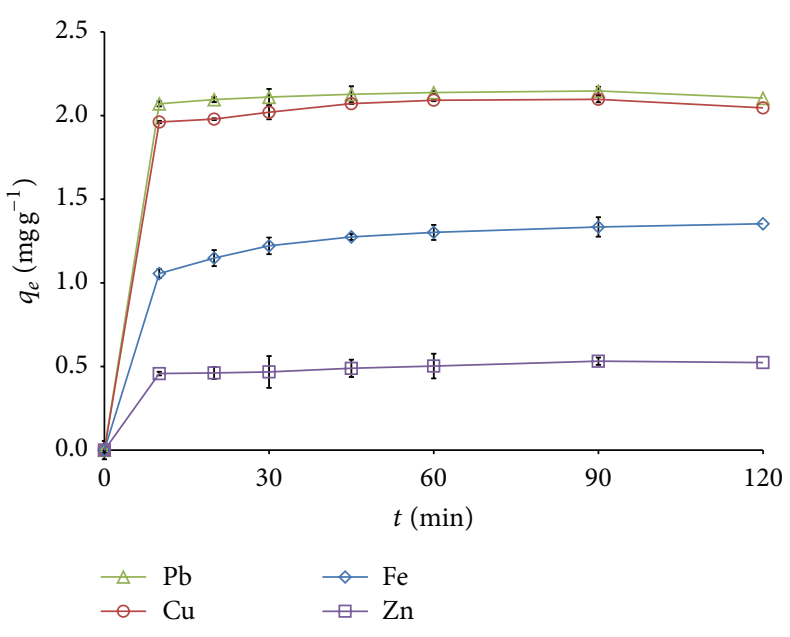

(b)

Figure 1: (a) Effect of solution pH on the metal ions biosorption onto Kappaphycus sp. dried biomass. (b) Effect of contact time on the metal ions biosorption onto Kappaphycus sp. dried biomass.

TABLE 2: Equations of the error function used in the study.

\begin{tabular}{|c|c|}
\hline Equation & Reference \\
\hline $\mathrm{SSE}=\sum_{i=1}^{n}\left(q_{e, \mathrm{calc}}-q_{e, \mathrm{exp}}\right)^{2}$ & [36] \\
\hline $\mathrm{ARE}=\frac{100}{N} \sum_{i=1}^{n}\left|q_{e, \exp }-q_{e, \mathrm{calc}}\right|$ & [36] \\
\hline HYBRID $=\frac{100}{(N-P)} \sum_{i=1}^{n} \frac{\left(q_{e, \exp }-q_{e, \text { calc }}\right)}{q_{e, \exp }}$ & [36] \\
\hline $\mathrm{EABS}=\sum_{i=1}^{n}\left|q_{e, \exp }-q_{e, \mathrm{calc}}\right|$ & [36] \\
\hline $\operatorname{MPSD}=100 \sqrt{\left(\frac{1}{N-P}\right) \sum_{i=1}^{n}\left(\frac{q_{e, \exp }-q_{e, \text { calc }}}{q_{e, \exp }}\right)^{2}}$ & [36] \\
\hline$\Delta q(\%)=100 \sqrt{\frac{1}{N-1} \sum_{i=1}^{n}\left(\frac{q_{e, \exp }-q_{e, \text { calc }}}{q_{e, \exp }}\right)^{2}}$ & [37] \\
\hline$r^{2}=\frac{\sum_{i=1}^{n}\left(q_{e, \mathrm{calc}}-\overline{q_{e, \exp }}\right)^{2}}{\sum_{i=1}^{n}\left(q_{e, \mathrm{calc}}-\overline{q_{e, \exp }}\right)^{2}+\sum_{i=1}^{n}\left(q_{e, \mathrm{calc}}-q_{e, \exp }\right)^{2}}$ & [38] \\
\hline$\chi^{2}=\sum_{i=1}^{n} \frac{\left(q_{e, \text { exp }}-q_{e, \text { calc }}\right)^{2}}{q_{e, \text { calc }}}$ & [39] \\
\hline $\mathrm{RMSE}=\sqrt{\frac{1}{N-2} \sum_{i=1}^{n}\left(q_{e, \exp }-q_{e, \text { calc }}\right)^{2}}$ & [40] \\
\hline
\end{tabular}

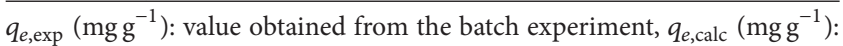
calculated value from the isotherm for corresponding $q_{e, \exp }, \overline{q_{e, \exp }}\left(\mathrm{mg} \mathrm{g}^{-1}\right)$ : mean of $q_{e, \exp }, N$ : number of observations in the experimental isotherm, and $P$ : number of parameters in the respective model.

3.3. Effect of Temperature. The solution temperature plays a vital role on the metal ions biosorption, which was found to increase with the increase of solution temperature. The rate of $\mathrm{Zn}^{2+}, \mathrm{Cu}^{2+}, \mathrm{Pb}^{2+}$, and $\mathrm{Fe}^{2+}$ biosorption by the dried biomass of Kappaphycus sp. was rapid reaching a maximum of $61.74,89.12,86.68$, and $40.06 \%$, respectively, at $50^{\circ} \mathrm{C}$. This phenomenon indicates that the biosorption process of the metal ions onto the biomass is endothermic. It can be attributed that, at the higher temperatures, the activation of the biosorbent surfaces is enlarged facilitating more active sites for biosorption of the metal ions. Moreover, an easy mobility and enhanced accessibility of metal ions from the bulk solution to the biomass active sites could also be the possible reason for the maximum biosorption of metal ions at higher temperatures [51].

3.4. Effect of Initial Metal Ion Concentration. Biosorption capacity of the biomass was found to increase with increasing initial concentration of the metal ions. This phenomenon can be attributed to an increase in electrostatic interactions involving sites of progressively lower affinity for the metal ions up to the point of saturation $[51,52]$. It was further observed that the percentage removal of the metal ions decreased markedly from $77.52 \%$ to $30.58 \%$ for $\mathrm{Zn}^{2+}, 87.52 \%$ to $36.09 \%$ for $\mathrm{Cu}^{2+}, 87.12 \%$ to $40.04 \%$ for $\mathrm{Pb}^{2+}$, and $80.72 \%$ to $31.52 \%$ for $\mathrm{Fe}^{2+}$ with an increase in the initial concentration of the metal ions from 25 to $200 \mathrm{mg} \mathrm{L}^{-1}$. This might be due to the rapid saturation of all metal binding active sites of the biosorbent at a certain concentration of the metal ions [52, 53] and an equilibrium state between adsorbate and biosorbent was attained.

3.5. Biosorption Isotherm Studies. The equilibrium adsorption isotherms are essential data source to design, understand, and optimize the biosorption process. The data express the intrinsic properties of the biosorbent and interaction between adsorbate and adsorbent. The data can be used to compare the biosorptive capacities of the biosorbent for different pollutants.

3.5.1. Langmuir Isotherm Model. The model isotherm parameters together with regression coefficient are represented in Table 3. As shown in Figure 2(a), approximately linear 
TABLE 3: Biosorption isotherm model parameters for the metal ions biosorption onto Kappaphycus sp. dried biomass.

\begin{tabular}{|c|c|c|c|c|c|}
\hline \multirow{2}{*}{ Model } & \multirow{2}{*}{ Parameter } & \multicolumn{4}{|c|}{ Metal ion } \\
\hline & & $\mathrm{Pb}^{2+}$ & $\mathrm{Cu}^{2+}$ & $\mathrm{Fe}^{2+}$ & $\mathrm{Zn}^{2+}$ \\
\hline \multirow{4}{*}{ Langmuir } & $q_{m}\left(\mathrm{mgg}^{-1}\right)$ & 22.17 & 19.49 & 16.92 & 16.23 \\
\hline & $K_{L}\left(\mathrm{~L} \mathrm{mg}^{-1}\right)$ & 0.0676 & 0.0728 & 0.073 & 0.0561 \\
\hline & $R_{L}$ & $0.37-0.07$ & $0.35-0.06$ & $0.35-0.06$ & $0.41-0.08$ \\
\hline & $R^{2}$ & 0.995 & 0.993 & 0.997 & 0.986 \\
\hline \multirow{3}{*}{ Freundlich } & $K_{F}\left(\mathrm{mg} \mathrm{g}^{-1}\right)\left(\mathrm{L} \mathrm{mg}^{-1}\right)^{1 / n}$ & 3.836 & 4.000 & 3.491 & 3.164 \\
\hline & $n$ & 2.744 & 3.091 & 3.104 & 3.121 \\
\hline & $R^{2}$ & 0.986 & 0.984 & 0.934 & 0.938 \\
\hline \multirow{3}{*}{ Temkin } & $A_{T}\left(\mathrm{~L} \mathrm{mg}^{-1}\right)$ & 1.037 & 1.397 & 1.228 & 1.056 \\
\hline & $b_{T}\left(\mathrm{~kJ} \mathrm{~mol}^{-1}\right)$ & 596.703 & 720.350 & 800.999 & 853.158 \\
\hline & $R^{2}$ & 0.991 & 0.995 & 0.989 & 0.967 \\
\hline \multirow{4}{*}{$\mathrm{D}-\mathrm{R}$} & $q_{m}\left(\mathrm{mgg}^{-1}\right)$ & 15.58 & 14.33 & 13.22 & 12.16 \\
\hline & $B_{D}\left(\mathrm{~mol}^{2} \mathrm{~kJ}^{-2}\right)$ & 2.284 & 2.224 & 4.773 & 5.768 \\
\hline & $R^{2}$ & 0.773 & 0.799 & 0.894 & 0.865 \\
\hline & $E\left(\mathrm{~kJ} \mathrm{~mol}^{-1}\right)$ & 0.468 & 0.474 & 0.324 & 0.294 \\
\hline
\end{tabular}

relationship $\left(R^{2} \geq 0.99\right)$ exists in the adsorption isotherms for Kappaphycus sp. The maximum Langmuir monolayer adsorption capacity of the sorbent, $q_{m}\left(\mathrm{mgg}^{-1}\right)$, for the experimental metal ions followed an increasing order: $\mathrm{Pb}^{2+}$ (22.27) $>\mathrm{Cu}^{2+}(19.46)>\mathrm{Fe}^{2+}(17.09)>\mathrm{Zn}^{2+}$ (16.78), suggesting that $\mathrm{Pb}^{2+}$ has a preferential uptake compared to the other metals, which can be attributed to its low tendency in forming strong complex [46]. Another reason might be attributed to carboxylate polysaccharides in seaweeds that show preferential binding of cations with large ionic radii [48]. However, the preferential sorption order of the metal ions in the present study can be explained by Pauling's electronegativity [54]: $\mathrm{Pb}^{2+}(2.33)>\mathrm{Cu}^{2+}(1.190)>\mathrm{Fe}^{2+}(1.83)$ $>\mathrm{Zn}^{2+}$ (1.65). This implies the fact that the higher the ion's electronegativity the higher the attraction for its electrons, and the attraction becomes stronger to the negative charge of the biomass ligands [55]. Furthermore, the separation factor, $R_{L}$, for the metal ions (Table 3 ) falls within the range of $0<$ $R_{L}<1$ suggesting that adsorption of the experimental ions is favourable at all the concentrations investigated [26]. Hence, the Kappaphycus sp. is a suitable biosorbent for the sorption of the experimental metal ions from aqueous solutions.

A comparative study on maximum heavy metal adsorption capacity of different low-cost adsorbents has been given in Table 4. The study shows that the dried biomass of Kappaphycus sp. is more promising than some other low-cost adsorbents for the removal of the metal ions.

3.5.2. Freundlich Isotherm Model. The linearized Freundlich isotherm model is shown in Figure 2(b); Freundlich constants $K_{F}$ and $n$ are represented in Table 3 . The results suggest that the biosorption of $\mathrm{Pb}^{2+}$ can be moderately described by the Freundlich model $\left(R^{2} \approx 0.99\right)$. The magnitude of Freundlich isotherm constant, $K_{F}$, suggests that the sorption capacity of the experimental metal ions was in the order of $\mathrm{Cu}^{2+}>\mathrm{Pb}^{2+}>\mathrm{Fe}^{2+}>\mathrm{Zn}^{2+}$. The values of $n>1$ suggest heterogeneity of the biomass surface, and the metal ions are favourably and intensively biosorbed by the dried biomass of Kappaphycus sp. under the experimental conditions.

3.5.3. Temkin Isotherm Model. The Temkin isotherm model indicates the adsorption potentials of the adsorbent for adsorbates. The Temkin isotherm plots (Figure 2(c)) and parameters (Table 3 ) indicate that the model fits the experimental data well $\left(R^{2} \geq 0.99\right)$ for describing the metal ions $\left(\mathrm{Pb}^{2+}, \mathrm{Cu}^{2+}\right.$, and $\left.\mathrm{Fe}^{2+}\right)$ adsorption. The lower values of the Temkin adsorption potential, $A_{T}\left(\mathrm{~L} \mathrm{mg}^{-1}\right)$, in the range of 0.769 to 1.455 indicate a lower sorbent-metal ion potential. Furthermore, the lower values (0.585-0.792) of the Temkin constant $b_{T}\left(\mathrm{~kJ} \mathrm{~mol}^{-1}\right)$ indicate a weak sorbatesorbent interaction [45].

3.5.4. D-R Isotherm Model. The D-R isotherm parameters (Table 3) indicate that the D-R model does not fit the experimental data well $\left(R^{2} \leq 0.89\right)$ for describing the metal ions biosorption, suggesting the involvement of metal sorption mechanisms other than van der Waals force [56]. The mean free energy of biosorption, $E\left(0.297-0.489 \mathrm{~kJ} \cdot \mathrm{mol}^{-1}\right)$, for the metal ions suggests that the sorption process is physisorption [57] and corroborative to the earlier reports in literature $[46,48]$. The positive values of $E$ indicate the endothermic nature of the sorption process [46]. Furthermore, the values of $E\left(<16 \mathrm{~kJ} \mathrm{~mol}^{-1}\right)$ suggest that the mechanism of the ion exchange process is film-diffusion controlled [58].

3.5.5. Competitive Adsorption. Competitive adsorption of the metal ions under quaternary system shows the adsorption preference of $\mathrm{Pb}^{2+}>\mathrm{Cu}^{2+}>\mathrm{Fe}^{2+}>\mathrm{Zn}^{2+}$ with the rate of metal removal as $90.39,90.00,75.00$, and $58.38 \%$, respectively. The results suggest that the potentiality of the adsorbent in the quaternary system remains the same as that in the single metal system, which proves its unique adsorption quality. 
TABLE 4: Maximum adsorption capacity of heavy metals by some low-cost sorbents.

\begin{tabular}{|c|c|c|c|c|c|}
\hline \multirow{2}{*}{ Low-cost sorbent } & \multicolumn{4}{|c|}{ Adsorption capacity $\left(\mathrm{mg} \mathrm{g}^{-1}\right)$} & \multirow{2}{*}{ Reference } \\
\hline & $\mathrm{Pb}^{2+}$ & $\mathrm{Cu}^{2+}$ & $\mathrm{Fe}^{2+}$ & $\mathrm{Zn}^{2+}$ & \\
\hline Activated carbon from coconut & 4.56 & - & - & - & [41] \\
\hline Activated carbon from seed hull of the palm tree & 3.58 & - & - & - & [41] \\
\hline Epichlorohydrin-crosslinked chitosan & 34.13 & 35.46 & - & 10.21 & {$[42]$} \\
\hline Hazelnut husk & 13.05 & 6.645 & - & - & {$[43]$} \\
\hline Natural muscovite & 0.63 & 0.618 & - & - & {$[44]$} \\
\hline Kaolinite & 7.75 & 4.42 & - & 4.95 & {$[45]$} \\
\hline Modified orange peel & 73.53 & 15.27 & - & - & {$[46]$} \\
\hline Coconut tree sawdust & 25.00 & 3.89 & - & 23.81 & [47] \\
\hline Sugarcane bagasse & 21.28 & 3.65 & - & 40.00 & {$[47]$} \\
\hline Kappaphycus sp. & 22.27 & 19.46 & 17.09 & 16.78 & Present study \\
\hline
\end{tabular}

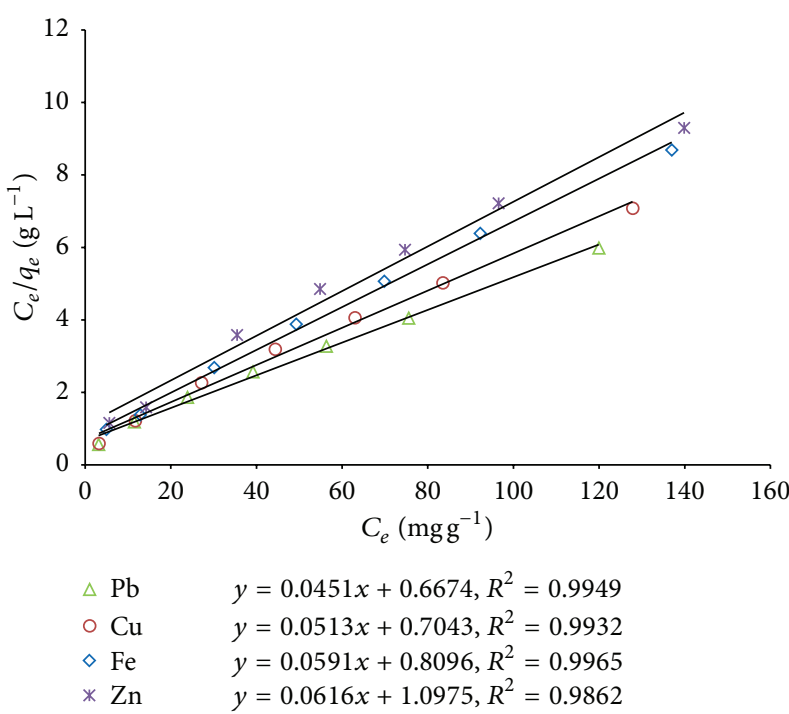

(a)



$$
\begin{array}{ll}
\triangle \mathrm{Pb} & y=0.3644 x+0.5839, R^{2}=0.9858 \\
\circ \mathrm{Cu} & y=0.3235 x+0.6021, R^{2}=0.9842 \\
\diamond \mathrm{Fe} & y=0.3222 x+0.543, R^{2}=0.934 \\
* \mathrm{Zn} & y=0.3204 x+0.5002, R^{2}=0.9377
\end{array}
$$

(b)

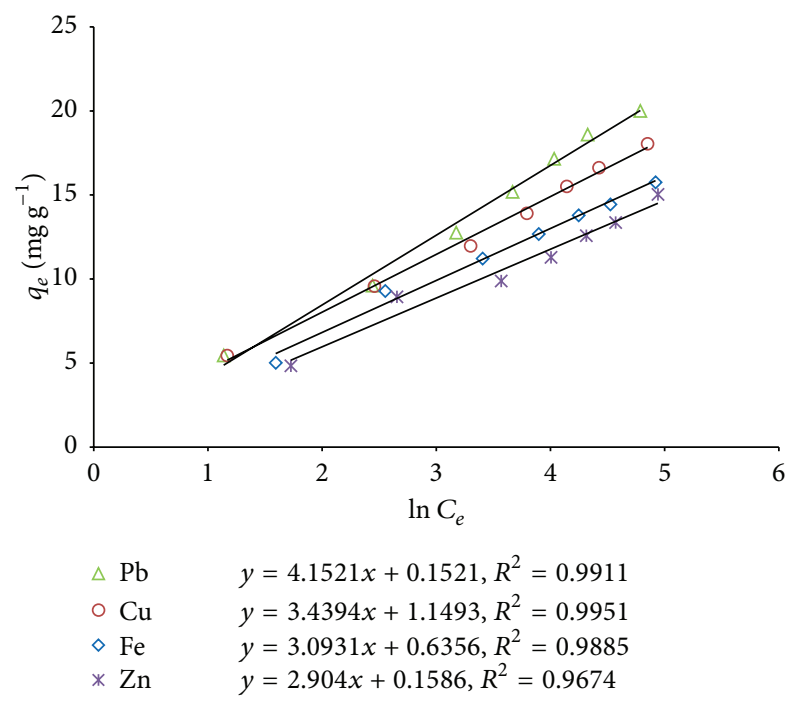

(c)

Figure 2: (a) Langmuir model for the metal ions biosorption onto Kappaphycus sp. dried biomass. (b) Freundlich model for the metal ions biosorption onto Kappaphycus sp. dried biomass. (c) Temkin model for the metal ions biosorption onto Kappaphycus sp. dried biomass. 
TABLE 5: Kinetic model parameters for the metal ions biosorption onto Kappaphycus sp. dried biomass.

\begin{tabular}{|c|c|c|c|c|c|}
\hline \multirow{2}{*}{ Model } & \multirow{2}{*}{ Parameter } & \multicolumn{4}{|c|}{ Metal ion } \\
\hline & & $\mathrm{Pb}^{2+}$ & $\mathrm{Cu}^{2+}$ & $\mathrm{Fe}^{2+}$ & $\mathrm{Zn}^{2+}$ \\
\hline & $q_{e, \exp }\left(\mathrm{mg} \mathrm{g}^{-1}\right)$ & 2.106 & 2.0467 & 1.3554 & 0.5255 \\
\hline \multirow{3}{*}{ Pseudo-first-order } & $k_{1}\left(\min ^{-1}\right)$ & 0.035 & 0.0435 & 0.0454 & 0.0329 \\
\hline & $q_{e, \text { calc }}\left(\mathrm{mg} \mathrm{g}^{-1}\right)$ & 0.1456 & 0.1162 & 0.53 & 0.1262 \\
\hline & $R^{2}$ & 0.986 & 0.997 & 0.995 & 0.974 \\
\hline \multirow{5}{*}{ Pseudo-second-order } & $k_{2}\left(\mathrm{~g} \mathrm{mg}^{-1} \mathrm{~min}^{-1}\right)$ & 0.6133 & 0.9047 & 0.1771 & 0.5968 \\
\hline & $q_{e, \text { calc }}\left(\mathrm{mg} \mathrm{g}^{-1}\right)$ & 2.1159 & 2.0559 & 1.3999 & 0.535 \\
\hline & $h\left(\mathrm{mgg} \mathrm{g}^{-1} \min ^{-1}\right)$ & 2.7457 & 3.8241 & 0.3471 & 0.1708 \\
\hline & $t_{1 / 2}(\min )$ & 0.7706 & 0.5376 & 4.0335 & 3.1322 \\
\hline & $R^{2}$ & 1.000 & 1.000 & 0.9999 & 0.9995 \\
\hline \multirow{3}{*}{ Elovich } & $\alpha\left(\mathrm{mg} \mathrm{g}^{-1} \min ^{-1}\right)$ & $5.67 \mathrm{E}+21$ & $1.62 \mathrm{E}+22$ & 62.4735 & 3276.307 \\
\hline & $\beta\left(\mathrm{g} \mathrm{mg}^{-1}\right)$ & 27.6243 & 28.8184 & 7.9618 & 27.0124 \\
\hline & $R^{2}$ & 0.9845 & 0.9318 & 0.9753 & 0.8817 \\
\hline \multirow{3}{*}{ Intraparticle diffusion } & $k_{d}\left(\mathrm{mg} \mathrm{g}^{-1} \min ^{-0.5}\right)$ & 0.0054 & 0.0099 & 0.0311 & 0.0112 \\
\hline & $C\left(\mathrm{mg} \mathrm{g}^{-1}\right)$ & 2.0457 & 1.9636 & 1.0597 & 0.4142 \\
\hline & $R^{2}$ & 0.985 & 0.988 & 0.965 & 0.997 \\
\hline
\end{tabular}

3.6. Biosorption Kinetic Studies. The kinetic data are essential to understand the rate and nature of adsorption onto the adsorbents. The data can be used to compare the kinetics of the biosorbent for different pollutants.

3.6.1. Pseudo-First-Order Kinetic Studies. As shown in Table 5 and Figure 3(a), the regression coefficient $\left(R^{2} \geq 0.99\right)$ of the pseudo-first-order model suggests that the experimental data accurately support the PFO model to describe adsorption kinetics of the metal ions. But the differences between the experimental values, $q_{e}$, were higher than the modelled values, $q_{m}$. It refers to the fact that both the metal ions and adsorbent were involved in the adsorption process [52]. Therefore, it is suggested that the pseudo-first-order model is not suitable to explain the kinetic sorption of the experimental metal ions onto the dried biomass of Kappaphycus sp. over the range of experimental time and metal ion concentrations. Similar results have been reported for the sorption kinetic of different metal ions onto different adsorbents including seaweeds in the literature $[51,52,59,60]$.

3.6.2. Pseudo-Second-Order Kinetic Model. The values of the regression coefficient of the linearized PSO kinetic model as shown in Figure 3(b) were the highest $\left(R^{2}>0.99\right)$ among the studied kinetic models, and the experimental $q_{e}$ values matched well with the calculated data (Table 5). Therefore, it can be suggested that the experimental data accurately support the best fit of the PSO model for the adsorption of the metal ions. Hence, chemisorption is the rate-limiting step which involves valence forces through the sharing or exchange of electrons between the metal ions and different functional groups in the sorbent $[13,60]$.

The pseudo-second-order rate constant, $k_{2}\left(\mathrm{~g} \mathrm{mg}^{-1} \mathrm{~min}^{-1}\right)$, was found in the range of 0.1874 to 0.9548 , which supports that the metal ions uptake onto the sorbent from aqueous solution was more rapid and favourable. As shown in
Figure 3(b), adsorption kinetic of the metal ions on Карраphycus sp. occurred in two steps: a fast initial uptake rate, $h\left(0.17-3.82 \mathrm{mg} \mathrm{g}^{-1} \mathrm{~min}^{-1}\right)$, in the first $30 \mathrm{~min}$, where more than $85 \%$ of the total metal adsorption occurred, followed by a slower uptake rate leading to the equilibrium state $(\sim 120 \mathrm{~min})$. Similar observation was reported in literature $[51,52]$. This phenomenon supports that the diffusion is the rate-controlling step in the sorption process [60]. The halfadsorption time $t_{1 / 2}(\mathrm{~min})$ defined as the time required for the adsorption to take up half amount of the equilibrium metal ions was found within the range of 0.54 to 4.03 indicating high affinity between the adsorbate and adsorbent molecules [61].

3.6.3. Elovich Model. The values of the regression coefficient $\left(R^{2}=0.79-0.98\right)$ of the Elovich kinetic model (Table 5, Figure 3(c)) suggest that kinetic data did not follow the Elovich model. However, the higher values of the Elovich constants, $\alpha\left(\mathrm{mgg}^{-1} \mathrm{~min}^{-1}\right)$ and $\beta\left(\mathrm{g} \mathrm{mg}^{-1}\right)$, as shown in Table 5 are suggestive of an increased rate of chemisorption [13].

3.6.4. Intraparticle Diffusion Model. The nonlinear regression data of $q_{t}$ versus $t^{0.5}$ plots as shown in Figure $3(\mathrm{~d})$ for different heavy metal ions suggests multilinearity (two phases in $\mathrm{Pb}^{2+}$ adsorption and three phases in $\mathrm{Cu}^{2+}, \mathrm{Fe}^{2+}$, and $\mathrm{Zn}^{2+}$ adsorption). The intraparticle diffusion rate constant $\left(k_{d}\right)$ as shown in Table 5 was obtained from the slope of the second linear portions of the plot of $q_{t}$ versus $t^{0.5}$ for the metal ions. Apparently intraparticle diffusion plays a significant role in the adsorption of $\mathrm{Pb}^{2+}, \mathrm{Cu}^{2+}$, and $\mathrm{Zn}^{2+}\left(R^{2} \geq 0.99\right)$ onto the dried biomass of Kappaphycus sp. suggesting the fact that there is a significant relationship between $q_{t}$ and $t^{0.5}$ for the metal ions at the experimental conditions. However, $q_{t}$ versus $t^{0.5}$ plots did not pass through the origin $(C>0)$ in any of the cases, suggesting that even though the adsorption 


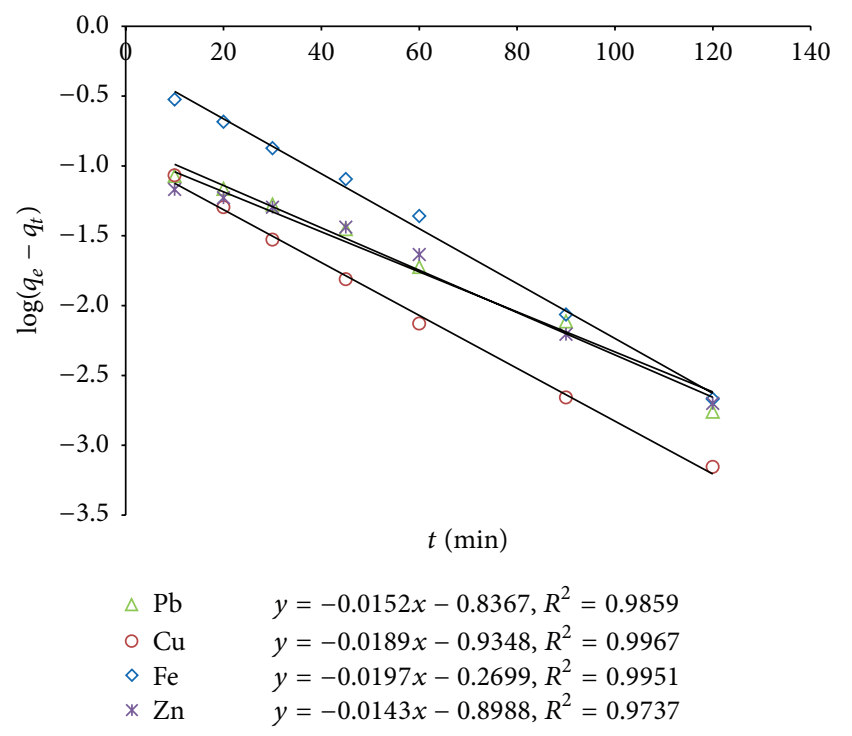

(a)

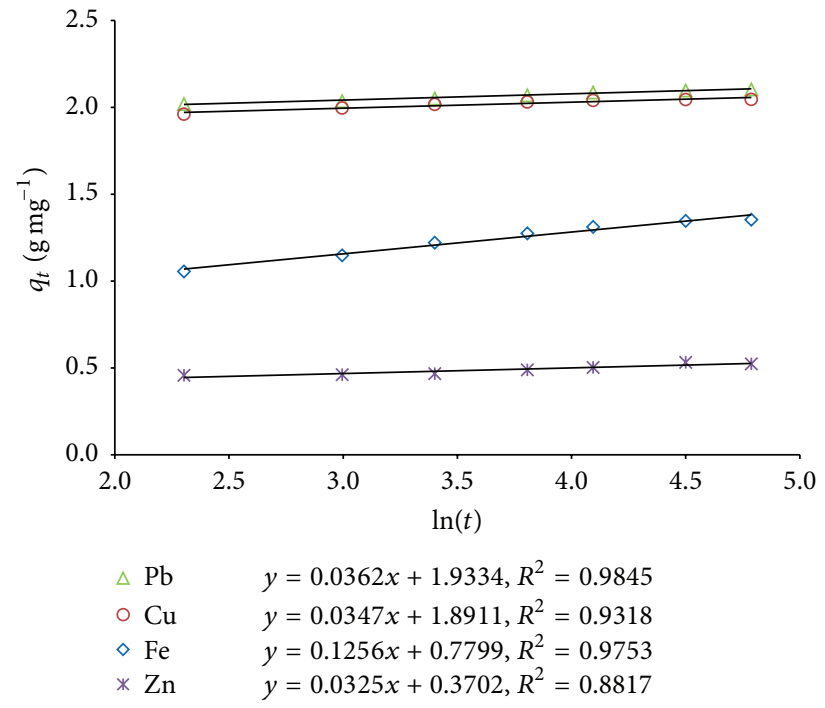

(c)



$\begin{array}{ll}\triangle \mathrm{Pb} & y=0.4726 x+0.3642, R^{2}=1.0000 \\ \circ \mathrm{Cu} & y=0.4864 x+0.2615, R^{2}=1.0000 \\ \diamond \mathrm{Fe} & y=0.7143 x+2.8811, R^{2}=0.9999 \\ * \mathrm{Zn} & y=1.8693 x+5.8551, R^{2}=0.9995\end{array}$

(b)

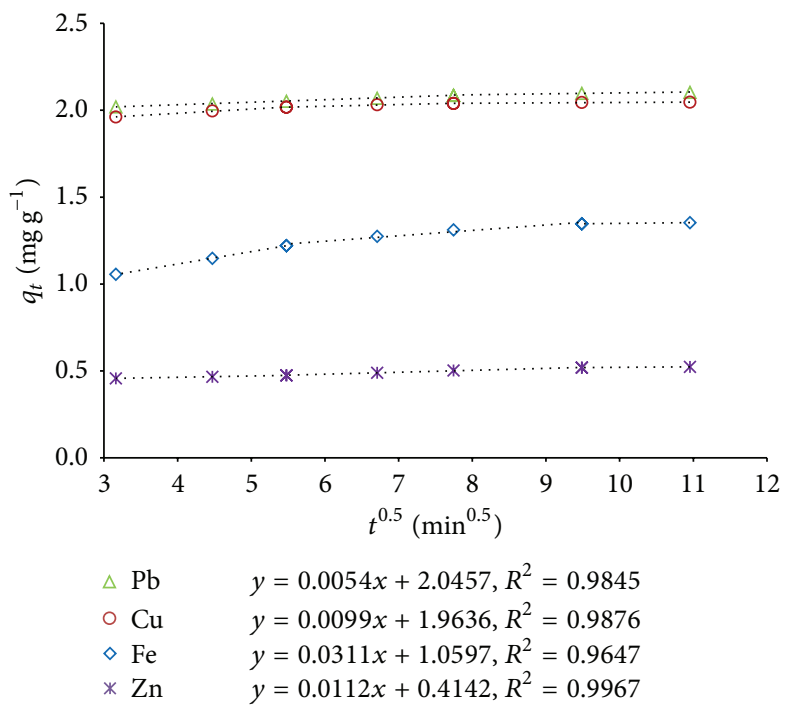

(d)

Figure 3: (a) Pseudo-first-order model for the metal ions biosorption onto Kappaphycus sp. dried biomass. (b) Pseudo-second-order model for the metal ions biosorption onto Kappaphycus sp. dried biomass. (c) Elovich model for the metal ions biosorption onto Kappaphycus sp. dried biomass. (d) Intraparticle diffusion model for the metal ions biosorption onto Kappaphycus sp. dried biomass.

process involved intraparticle diffusion, it was not the only rate-controlling step $[13,62]$, and external mass transfer had also played an important role in the metal ions sorption by the dried biomass of Kappaphycus sp. [13].

3.7. Thermodynamic Studies. The values of the thermodynamic parameters are shown in Table 6. The linearized Van't Hoff plots of $\ln \left(K_{\text {eq }}\right)$ versus 1/T are represented in Figure 4. The negative values of $\Delta G^{\circ}$ indicate that the thermodynamic process was spontaneous and feasible for all the tested metal ions [35]. Moreover, the increase in negative $\Delta G^{\circ}$ values with an increase in temperature shows an increased feasibility of adsorption at higher temperature, which is corroborative to the earlier reports $[48,52,59]$.
The positive values of enthalpy change $\left(\Delta H^{\circ}\right)$ suggest endothermic nature of the metal adsorption process $[13,51$, $59,63,64]$. In addition, the extent of enthalpy value gives indicative information on the type of biosorption, which can be either physical or chemical. The enthalpy change $\left(\Delta H^{\circ}\right)$ in the range of 2.1-20.9, 20.9-80.0, and $80.0-418.4 \mathrm{~kJ} \mathrm{~mol}^{-1}$ is indicative of physisorption, physisorption together with chemisorptions, and chemisorptions, respectively [48]. Based on the values of $\Delta H^{\circ}$, it can be presumed that the biosorption process took place physically for all the tested metal ions. This was also supported by D-R isotherm results with the $E\left(<8 \mathrm{~kJ} \mathrm{~mol}^{-1}\right)$ values of the metal ions (Table 3). Further, positive values of entropy change $\left(\Delta S^{\circ}\right)$ are suggestive of increased randomness at the solid-solution interface during 
TABLE 6: Thermodynamic parameters for the metal ions biosorption onto Kappaphycus sp. dried biomass.

\begin{tabular}{lccccrrr}
\hline Metal ion & $\Delta H^{\circ}$ & $\Delta S^{\circ}$ & \multicolumn{2}{c}{$\Delta G^{\circ}\left(\mathrm{kJ} \mathrm{mol}^{-1}\right)$} & \\
& $\left(\mathrm{kJ} \mathrm{mol}^{-1}\right)$ & $\left(\mathrm{kJ} \mathrm{mol}^{-1} \mathrm{~K}^{-1}\right)$ & $298^{\circ} \mathrm{K}$ & $303^{\circ} \mathrm{K}$ & $313^{\circ} \mathrm{K}$ & $323^{\circ} \mathrm{K}$ \\
\hline $\mathrm{Pb}^{2+}$ & 16.4501 & 57.5745 & -0.7071 & -0.9950 & -34.4709 & -35.0466 \\
$\mathrm{Cu}^{2+}$ & 11.7518 & 40.4642 & -23.8102 & -24.0125 & -24.4171 & -24.8218 & 0.999 \\
$\mathrm{Fe}^{2+}$ & 10.0799 & 23.6583 & -17.1301 & -17.2484 & -17.4849 & -17.7215 & 0.999 \\
$\mathrm{Zn}^{2+}$ & 29.4432 & 80.7755 & -53.5143 & -53.9182 & -54.7259 & -55.5337 & 0.999 \\
\hline
\end{tabular}

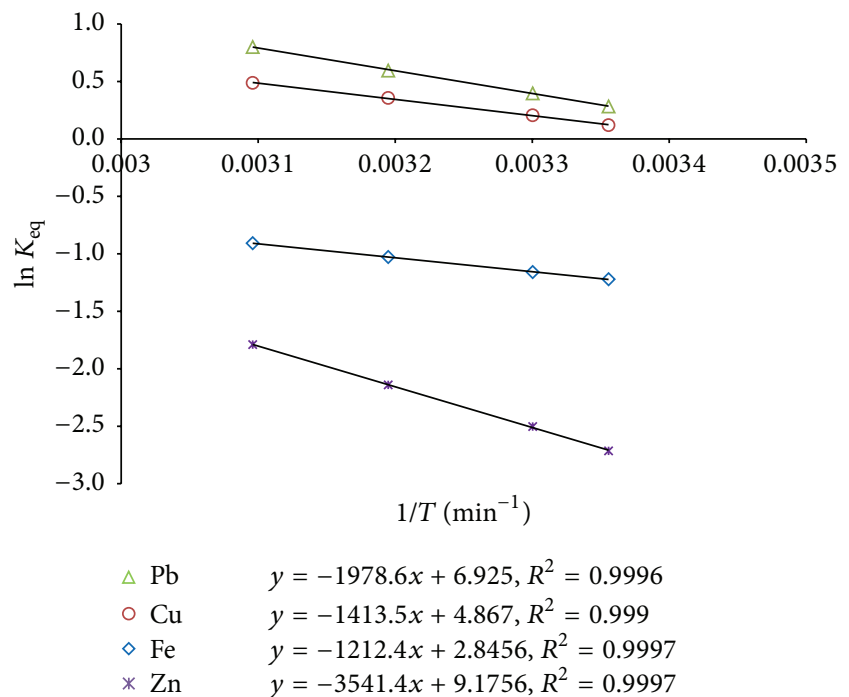

Figure 4: Van't Hoff plots for the metal ions biosorption onto Kappaphycus sp. dried biomass.

the biosorption process of the metal ions on the active sites of the biosorbent [59].

3.8. Error Function. In the real-world, data samples from each experiment in a series of experiments differ due to measurement error affecting data precision. In order to ensure accurate measurement results, statistical error function is the measure to compensate data errors [65]. Hence, the isotherm and kinetic data were further analyzed using nine error functions in order to test the fitness of the models. Lower value of SSE, ARE, HYBRID, EABS, MPSD, $\chi^{2}, \Delta q(\%)$, and $R M S E$ and higher value of $r^{2}$ indicate the best fit of the model.

The correlation of regression $\left(R^{2}\right)$ for the adsorption isotherm models (Table 3 ) suggests that $\mathrm{Pb}^{2+}, \mathrm{Fe}^{2+}$, and $\mathrm{Zn}^{2+}$ follow the Langmuir model while $\mathrm{Cu}^{2+}$ follows the Temkin model accurately. The error functions of the isotherm data (Table 7) suggest that the Temkin model provides the best fit to the experimental data. Again, the correlation of regression $\left(R^{2}\right)$ for the kinetic models (Table 5) shows that PSO is the best fit model. But the error functions of the kinetic data (Table 8) suggest that the best fit of the kinetic models is intraparticle diffusion. It is, therefore, strongly suggested that the regression coefficient $\left(R^{2}\right)$ is not an appropriate method for comparing the best fitting of the isotherm and kinetic models; rather some forms of error analysis could be a better criterion for avoiding data errors.



FIGURE 5: FTIR spectra of the functional groups in Kappaphycus sp. biomass before and after biosorption of the metal ions.

3.9. FTIR Spectral Analysis. The FTIR spectra of Kappaphycus $\mathrm{sp}$. (Figure 5) consist of a number of absorption peaks which indicate complex nature of the biomass. The strong broad peak observed at $3358.1 \mathrm{~cm}^{-1}$ in the raw biomass corresponds to $\mathrm{O}-\mathrm{H}$ group from cellulose and $\mathrm{N}-\mathrm{H}$ groups from proteins in the seaweed [66]. In the spectra other dominant peaks were observed at wavenumbers $\left(\mathrm{cm}^{-1}\right)$ 2917.1, 1636.5, 1375.0, $1220.1,1155.1,1035.2,924.0$, and 842.9 which are characterized to the asymmetric $\mathrm{C}-\mathrm{H}$ stretching vibrations of the aliphatic groups [67], $\mathrm{C}=\mathrm{O}$ stretching vibration of carboxylate groups $[48,60]$, asymmetric stretching of $-\mathrm{SO}_{3}{ }^{-}$bonds in sulfonic acid [48], $\mathrm{C}=\mathrm{O}$ stretching vibration of carboxylate groups $[48,60]$, symmetric stretching of $-\mathrm{SO}_{3}{ }^{-}$bonds in sulfonic acid [48], C-O stretching vibration of carboxyl groups [60], $\mathrm{S}-\mathrm{O}$ stretching [60], and $\mathrm{S}=\mathrm{O}$ stretching bands of sulfonate groups [48], respectively.

After biosorption of $\mathrm{Pb}^{2+}$ the peaks were shifted to $3355.9,2917.8,1638.8,1370.4,1222.0,1154.1,1033.5,924.8$, and $844.5 \mathrm{~cm}^{-1}$, respectively. After biosorption of $\mathrm{Cu}^{2+}$ the peaks were changed to $3324.7,2919.9,1638.3,1370.5,1216.0$, $1153.3,1032.7,925.3$, and $845.9 \mathrm{~cm}^{-1}$, respectively. The peaks after $\mathrm{Fe}^{2+}$ biosorption were changed to 3351.9, 2916.8, 1637.2, $1369.2,1223.9,1154.5,1032.1,925.2$, and $844.2 \mathrm{~cm}^{-1}$, respectively. After biosorption of $\mathrm{Zn}^{2+}$ the peaks were shifted to $3328.4,2918.1,1636.9,1370.3,1221.1,1154.2,1030.9,924.7$, and $845.3 \mathrm{~cm}^{-1}$, respectively. In the quaternary system, the peaks after biosorption were shifted to $3348.3,2918.0,1636.1,1355.1$, $1224.0,1154.9,1033.1,924.9$, and $845.1 \mathrm{~cm}^{-1}$, respectively. 
TABLE 7: Error function data of the isotherm models.

\begin{tabular}{llccccccccc}
\hline \multirow{2}{*}{ Metal ion } & Isotherm model & \multicolumn{1}{c}{ Error function } \\
& & SSE & ARE & HYBRID & EABS & MPSD & $r^{2}$ & $\chi^{2}$ & $\Delta q(\%)$ & RMSE \\
\hline \multirow{3}{*}{$\mathrm{Pb}^{2+}$} & Langmuir & 4.4347 & 6.7140 & 9.3996 & 4.2033 & 34.7188 & 0.9774 & 0.7927 & 12.6314 & 0.94177 \\
& Freundlich & 4.9053 & 4.3967 & 6.1554 & 4.3317 & 23.7746 & 0.9739 & 0.2681 & 5.5740 & 0.99049 \\
& Temkin & 1.4457 & 3.9218 & 5.4905 & 2.7612 & 17.4775 & 0.9911 & 0.1572 & 5.6824 & 0.53772 \\
& Dubinin-Radushkevich & 58.3244 & 17.0502 & 23.8703 & 16.5533 & 92.0214 & 0.5995 & 3.8955 & 23.8712 & 3.41539 \\
\hline \multirow{3}{*}{$\mathrm{Cu}^{2+}$} & Langmuir & 5.7968 & 8.5817 & 12.0143 & 5.3808 & 39.3515 & 0.9629 & 1.0282 & 14.1340 & 1.07674 \\
& Freundlich & 2.2807 & 4.0093 & 5.6130 & 3.2226 & 18.7862 & 0.9826 & 0.1747 & 5.2390 & 0.67538 \\
& Temkin & 0.5693 & 2.1797 & 3.0515 & 1.7002 & 10.1114 & 0.9951 & 0.05078 & 3.0016 & 0.33742 \\
& Dubinin-Radushkevich & 37.5579 & 14.6298 & 20.4817 & 13.3928 & 75.4605 & 0.6420 & 2.7153 & 19.7375 & 2.74073 \\
\hline \multirow{3}{*}{} & Langmuir & 2.3495 & 5.4061 & 7.5685 & 3.6433 & 22.5599 & 0.9760 & 0.2778 & 7.1832 & 0.68549 \\
$\mathrm{Fe}^{2+}$ & Freundlich & 5.1830 & 7.6257 & 10.6759 & 5.2617 & 32.1906 & 0.9476 & 0.5282 & 10.0870 & 1.01814 \\
& Temkin & 0.9198 & 3.0795 & 4.31124 & 1.6626 & 15.7644 & 0.9885 & 0.1240 & 5.5745 & 0.42890 \\
& Dubinin-Radushkevich & 14.9728 & 10.1415 & 14.1981 & 8.5372 & 48.9560 & 0.7916 & 1.1939 & 12.9975 & 1.73048 \\
\hline \multirow{3}{*}{$\mathrm{Zn}^{2+}$} & Langmuir & 6.4809 & 9.6783 & 13.5496 & 6.0631 & 38.6885 & 0.9325 & 0.8625 & 12.6706 & 1.13850 \\
& Freundlich & 3.0423 & 5.2872 & 7.4021 & 3.0394 & 27.2346 & 0.9602 & 0.4149 & 9.0515 & 0.78004 \\
& Temkin & 2.2050 & 4.9041 & 6.8658 & 3.2227 & 21.6034 & 0.9674 & 0.2471 & 6.6271 & 0.66408 \\
& Dubinin-Radushkevich & 16.4718 & 10.9989 & 15.3985 & 8.8422 & 51.8019 & 0.7325 & 1.3963 & 13.8314 & 1.81504 \\
\hline
\end{tabular}

TABLE 8: Error function data of the kinetic models.

\begin{tabular}{|c|c|c|c|c|c|c|c|c|c|c|}
\hline \multirow{2}{*}{ Metal ion } & \multirow{2}{*}{ Kinetic model } & \multicolumn{9}{|c|}{ Error function } \\
\hline & & SSE & ARE & HYBRID & EABS & MPSD & $r^{2}$ & $\chi^{2}$ & $\Delta q(\%)$ & RMSE \\
\hline \multirow{4}{*}{$\mathrm{Pb}^{2+}$} & Pseudo-first-order & 25.7891 & 92.8427 & 129.9800 & 13.4342 & 157.948 & 0.49997 & 178.767 & 100.288 & 2.27108 \\
\hline & Pseudo-second-order & 0.003366 & 0.56776 & 0.79486 & 0.08086 & 1.82415 & 0.80927 & 0.00171 & 1.17070 & 0.02595 \\
\hline & Elovich & $9.30 \mathrm{E}-05$ & 0.16020 & 0.22428 & 0.02312 & 0.30064 & 0.98456 & $4.52 \mathrm{E}-05$ & 0.19128 & 0.00431 \\
\hline & Intraparticle diffusion & $2.39 \mathrm{E}-06$ & 0.03899 & 0.11698 & 0.00245 & 0.10672 & 0.98437 & $1.14 \mathrm{E}-06$ & 0.05210 & 0.00155 \\
\hline \multirow{4}{*}{$\mathrm{Cu}^{2+}$} & Pseudo-first-order & 25.3581 & 94.2342 & 131.928 & 13.3208 & 158.455 & 0.49992 & 220.398 & 101.787 & 2.25202 \\
\hline & Pseudo-second-order & 0.00015 & 0.16029 & 0.22440 & 0.02232 & 0.38712 & 0.97869 & $7.51 \mathrm{E}-05$ & 0.25151 & 0.00544 \\
\hline & Elovich & 0.00040 & 0.33223 & 0.46512 & 0.04693 & 0.62860 & 0.93190 & 0.00020 & 0.40416 & 0.00893 \\
\hline & Intraparticle diffusion & $3.29 \mathrm{E}-06$ & 0.05087 & 0.15262 & 0.00310 & 0.12720 & 0.98718 & $1.62 \mathrm{E}-06$ & 0.06311 & 0.00181 \\
\hline \multirow{4}{*}{$\mathrm{Fe}^{2+}$} & Pseudo-first-order & 3.49809 & 56.1628 & 78.6279 & 4.90190 & 74.5604 & 0.49752 & 6.56855 & 60.8816 & 0.83643 \\
\hline & Pseudo-second-order & 0.00400 & 1.35554 & 1.89776 & 0.10685 & 2.72686 & 0.95949 & 0.00390 & 2.40267 & 0.02828 \\
\hline & Elovich & 0.00181 & 1.13760 & 1.59264 & 0.09939 & 1.68403 & 0.97531 & 0.00141 & 1.36581 & 0.01902 \\
\hline & Intraparticle diffusion & 0.00031 & 0.66725 & 1.33449 & 0.03436 & 1.08937 & 0.96472 & 0.00024 & 0.78427 & 0.01236 \\
\hline \multirow{4}{*}{$\mathrm{Zn}^{2+}$} & Pseudo-first-order & 0.92442 & 73.8117 & 103.336 & 2.53393 & 61.3141 & 0.49932 & 7.65727 & 79.9178 & 0.42998 \\
\hline & Pseudo-second-order & 0.00279 & 2.59220 & 3.62908 & 0.08525 & 3.48380 & 0.77805 & 0.00673 & 4.68899 & 0.02363 \\
\hline & Elovich & 0.00064 & 1.63635 & 2.29089 & 0.05555 & 1.62276 & 0.88172 & 0.00133 & 2.12691 & 0.01133 \\
\hline & Intraparticle diffusion & $3.87 \mathrm{E}-06$ & 0.18119 & 0.36239 & 0.00362 & 0.19597 & 0.99645 & $7.68 \mathrm{E}-06$ & 0.22567 & 0.00139 \\
\hline
\end{tabular}

The significant change in the intensity of the peaks shows interaction between the metal ions and the functional groups. Because intensity depends on change in dipole moment and total number of functional groups present on biosorbent surface. Therefore, it can be concluded that the carboxylic, sulfonic acid, and sulfonate groups of Kappaphycus sp. dried biomass are involved in the biosorption of the metal ions.

\section{Conclusion}

In the present study, we examined adsorption of four heavy metal ions such as $\mathrm{Pb}^{2+}, \mathrm{Cu}^{2+}, \mathrm{Fe}^{2+}$, and $\mathrm{Zn}^{2+}$ onto the dried biomass of the red seaweed Kappaphycus sp. from Malaysia.
The adsorption isotherm data for the metal ions fitted well with the Temkin model followed. Kinetic data for all the metal ions can be best described by the intraparticle diffusion model. Adsorption process was feasible, spontaneous, and endothermic in nature. We strongly suggest that analysis of error functions is a better criterion for validating isotherm and kinetic models in order to evaluate adsorptive behaviour of a typical adsorbent using linear method.

Heavy metal adsorption process onto the dried biomass of Kappaphycus sp. was the complex one involving more than one mechanism. Both homogeneous and heterogeneous active sites were found to exist in the dried biomass. The FTIR study revealed the presence of carboxylic, sulfonic 
acid, and sulfonate groups in the cell wall matrix of the biomass that was involved in the adsorption of the metal ions. The dried biomass of Kappaphycus sp. may be used as a low-cost biosorbent for removal of heavy metal ions from aqueous solutions. Further study is warranted to evaluate the potentiality of the biosorbent for heavy metal removal from the real environment.

\section{Conflict of Interests}

The authors hereby declare no conflict of interests.

\section{Acknowledgment}

The authors greatly acknowledge the financial support of the AIMST University (AURGC/1/FAS/2013) for the research.

\section{References}

[1] R. K. Gautam, S. K. Sharma, S. Mahiya, and M. C. Chattopadhyaya, "Contamination of heavy metals in aquatic media: transport, toxicity and technologies for remediation," in Heavy Metals In Water: Presence, Removal and Safety, S. K. Sharma, Ed., pp. 1-24, The Royal Society of Chemistry, Cambridge, UK, 2015.

[2] S.-L. Wang, X.-R. Xu, Y.-X. Sun, J.-L. Liu, and H.-B. Li, "Heavy metal pollution in coastal areas of South China: a review," Marine Pollution Bulletin, vol. 76, no. 1-2, pp. 7-15, 2013.

[3] A. Sarkar, J. Bhagat, and S. Sarker, "Evaluation of impairment of DNA in marine gastropod, Morula granulata as a biomarker of marine pollution," Ecotoxicology and Environmental Safety, vol. 106, pp. 253-261, 2014.

[4] P. Chowdhury, A. Elkamel, and A. K. Ray, "Photocatalytic processes for the removal of toxic metal ions," in Heavy Metals in Water: Presence, Removal and Safety, S. K. Sharma, Ed., pp. 25-43, The Royal Society of Chemistry, Cambridge, UK, 2015.

[5] M. Zhang, B. Gao, J. Jin et al., "Use of nanotechnology against heavy metals present in water," in Heavy Metals in Water: Presence, Removal and Safety, S. K. Sharma, Ed., pp. 177-192, The Royal Society of Chemistry, Cambridge, UK, 2015.

[6] S. Majumder, S. Gupta, and S. Raghuvanshi, "Removal of dissolved metals by bioremediation," in Heavy Metals in Water: Presence, Removal and Safety, S. K. Sharma, Ed., pp. 44-56, The Royal Society of Chemistry, Cambridge, UK, 2015.

[7] J. He and J. P. Chen, "A comprehensive review on biosorption of heavy metals by algal biomass: materials, performances, chemistry, and modeling simulation tools," Bioresource Technology, vol. 160, pp. 67-78, 2014.

[8] T. Macek and M. Mackova, "Potential of biosorption technology," in Microbial Biosorption of Metals, P. Kotrba, M. Mackova, and T. Macek, Eds., pp. 7-17, Springer Netherlands, 2011.

[9] M. Grassi, G. Kaykioglu, V. Belgiorno, and G. Lofrano, "Removal of emerging contaminants from water and wastewater by adsorption process," in Emerging Compounds Removal from Wastewater, G. Lofrano, Ed., pp. 15-37, Springer Netherlands, 2012.

[10] M. Bilal, J. A. Shah, T. Ashfaq et al., "Waste biomass adsorbents for copper removal from industrial wastewater-a review," Journal of Hazardous Materials, vol. 263, part 2, pp. 322-333, 2013.
[11] I. Michalak, K. Chojnacka, and A. Witek-Krowiak, "State of the art for the biosorption process-a review," Applied Biochemistry and Biotechnology, vol. 170, no. 6, pp. 1389-1416, 2013.

[12] M. Fomina and G. M. Gadd, "Biosorption: current perspectives on concept, definition and application," Bioresource Technology, vol. 160, pp. 3-14, 2014.

[13] M. Rathod, K. Mody, and S. Basha, "Efficient removal of phosphate from aqueous solutions by red seaweed, Kappaphycus alverezii," Journal of Cleaner Production, vol. 84, no. 1, pp. 484493, 2014.

[14] V. Webber, S. M. de Carvalho, and P. L. M. Barreto, "Molecular and rheological characterization of carrageenan solutions extracted from Kappaphycus alvarezii," Carbohydrate Polymers, vol. 90, no. 4, pp. 1744-1749, 2012.

[15] FAO, Global Aquaculture Production 1950-2012, 2015, http:// www.fao.org/fishery/statistics/global-aquaculture-production/ query/en.

[16] O. L. Kang, N. Ramli, M. Said, M. Ahmad, S. M. Yasir, and A. Ariff, "Kappaphycus alvarezii waste biomass: a potential biosorbent for chromium ions removal," Journal of Environmental Sciences, vol. 23, no. 6, pp. 918-922, 2011.

[17] K. O. Lee, N. Ramli, M. Said, M. Ahmad, S. M. Yasir, and A. Ariff, "Copper (II) and nickel (II) sorption onto seaweed (Kappaphycus alvarezii) waste biomass: equilibrium and mechanism studies," Middle-East Journal of Scientific Research, vol. 9, no. 1, pp. 84-89, 2011.

[18] D. Park, Y.-S. Yun, and J. M. Park, “The past, present, and future trends of biosorption," Biotechnology and Bioprocess Engineering, vol. 15, no. 1, pp. 86-102, 2010.

[19] S. Basha, S. Jaiswar, and B. Jha, "On the biosorption, by brown seaweed, Lobophora variegata, of $\mathrm{Ni}$ (II) from aqueous solutions: equilibrium and thermodynamic studies," Biodegradation, vol. 21, no. 5, pp. 661-680, 2010.

[20] H. Qiu, L. Lv, B.-C. Pan, Q.-J. Zhang, W.-M. Zhang, and Q.-X. Zhang, "Critical review in adsorption kinetic models," Journal of Zhejiang University SCIENCE A, vol. 10, no. 5, pp. 716-724, 2009.

[21] S. Sen Gupta and K. G. Bhattacharyya, "Kinetics of adsorption of metal ions on inorganic materials: a review," Advances in Colloid and Interface Science, vol. 162, no. 1-2, pp. 39-58, 2011.

[22] W. Plazinski and A. Plazinska, "Equilibrium and kinetic modeling of adsorption at solid/solution interface," in Application of Adsorbents for Water Pollution Control, A. Bhatnagar, Ed., pp. 32-80, Bentham Science Publishers, AG Bussum, The Netherlands, 2012.

[23] K. E. Carpenter and V. H. E. Niem, FAO Species Identification Guide for Fishery Purposes. The Living Marine Resources of the Western Central Pacific. Volume 1. Seaweeds, Corals, Bivalves and Gastropods, FAO, Rome, Italy, 1998.

[24] A. R. Sherwood, A. Kurihara, K. Y. Conklin, T. Sauvage, and G. G. Presting, "The Hawaiian Rhodophyta Biodiversity Survey (2006-2010): a summary of principal findings," BMC Plant Biology, vol. 10, article 258, 2010.

[25] I. Langmuir, "The adsorption of gases on plane surfaces of glass, mica and platinum," The Journal of the American Chemical Society, vol. 40, no. 9, pp. 1361-1403, 1918.

[26] T. W. Weber and R. K. Chakravorti, "Pore and solid diffusion models for fixed-bed adsorbers," AIChE Journal, vol. 20, no. 2, pp. 228-238, 1974.

[27] H. M. F. Freundlich, "Über die adsorption in lösungen," Zeitschrift für Physikalische Chemie (Leipzig), vol. 57A, pp. 385470, 1906. 
[28] S. Z. Roginsky and Y. B. Zeldovich, "Die katalische oxidation von kohlenmonoxyd auf mangandioxyd," Acta Physiochimica URSS, vol. 1, no. 3-4, pp. 554-594, 1934.

[29] M. M. Dubinin and L. V. Radushkevich, "Equation of the characteristic curve of the activated charcoal," Chemisches Zentralblatt, vol. 1, no. 1, pp. 875-890, 1947.

[30] J. P. Hobson, "Physical adsorption isotherms extending from ultrahigh vacuum to vapor pressure," The Journal of Physical Chemistry, vol. 73, no. 8, pp. 2720-2727, 1969.

[31] S. Y. Lagergren, "Zur theorie der sogenannten adsorption gelöster Stoffe," Kongliga Svenska Vetenskaps-Akademiens Handlingar, vol. 24, no. 4, pp. 1-39, 1898.

[32] Y.-S. Ho, Adsorption of heavy metals from waste streams by peat [Ph.D. thesis], University of Birmingham, Birmingham, UK, 1995.

[33] S. H. Chien and W. R. Clayton, "Application of elovich equation to the kinetics of phosphate release and sorption in soilsl," Soil Science Society of America Journal, vol. 44, no. 2, pp. 265-268, 1980.

[34] W. J. Weber and J. C. Morris, "Kinetics of adsorption on carbon from solution," Journal of the Sanitary Engineering Division, vol. 89, no. 2, pp. 31-60, 1963.

[35] J. W. Gibbs, "A method of geometrical representation of the thermodynamic properties of substances by means of surfaces," Transactions of the Connecticut Academy of Arts and Sciences, vol. 2, pp. 382-404, 1873.

[36] B. Subramanyam and A. Das, "Linearised and non-linearised isotherm models optimization analysis by error functions and statistical means," Journal of Environmental Health Science \& Engineering, vol. 12, no. 1, article 92, 2014.

[37] L. Wang, J. Zhang, R. Zhao, Y. Li, C. Li, and C. Zhang, "Adsorption of $\mathrm{Pb}(\mathrm{II})$ on activated carbon prepared from Polygonum orientale Linn.: kinetics, isotherms, $\mathrm{pH}$, and ionic strength studies," Bioresource Technology, vol. 101, no. 15, pp. 5808-5814, 2010.

[38] J. He, S. Hong, L. Zhang, F. Gan, and Y.-S. Ho, "Equilibrium and thermodynamic parameters of adsorption of methylene blue onto rectorite," Fresenius Environmental Bulletin, vol. 19, no. 11, pp. 2651-2656, 2010.

[39] Y.-S. Ho and A. E. Ofomaja, "Pseudo-second-order model for lead ion sorption from aqueous solutions onto palm kernel fiber," Journal of Hazardous Materials, vol. 129, no. 1-3, pp. 137142, 2006.

[40] K. Vijayaraghavan, T. V. N. Padmesh, K. Palanivelu, and M. Velan, "Biosorption of nickel(II) ions onto Sargassum wightii: application of two-parameter and three-parameter isotherm models," Journal of Hazardous Materials, vol. 133, no. 1-3, pp. 304-308, 2006.

[41] S. Gueu, B. Yao, K. Adouby, and G. Ado, "Kinetics and thermodynamics study of lead adsorption on to activated carbons from coconut and seed hull of the palm tree," International Journal of Environmental Science \& Technology, vol. 4, no. 1, pp. 11-17, 2007.

[42] A.-H. Chen, S.-C. Liu, C.-Y. Chen, and C.-Y. Chen, "Comparative adsorption of $\mathrm{Cu}(\mathrm{II}), \mathrm{Zn}(\mathrm{II})$, and $\mathrm{Pb}$ (II) ions in aqueous solution on the crosslinked chitosan with epichlorohydrin," Journal of Hazardous Materials, vol. 154, no. 1-3, pp. 184-191, 2008.

[43] M. Imamoglu and O. Tekir, "Removal of copper (II) and lead (II) ions from aqueous solutions by adsorption on activated carbon from a new precursor hazelnut husks," Desalination, vol. 228, no. 1-3, pp. 108-113, 2008.
[44] J.-S. Yang, J. Y. Lee, Y.-T. Park, K. Baek, and J. Choi, “Adsorption of $\mathrm{As}(\mathrm{III}), \mathrm{As}(\mathrm{V}), \mathrm{Cd}(\mathrm{II}), \mathrm{Cu}(\mathrm{II})$, and $\mathrm{Pb}(\mathrm{II})$ from aqueous solutions by natural muscovite," Separation Science and Technology, vol. 45, no. 6, pp. 814-823, 2010.

[45] S. Shahmohammadi-Kalalagh, H. Babazadeh, A. H. Nazemi, and M. Manshouri, "Isotherm and kinetic studies on adsorption of $\mathrm{Pb}, \mathrm{Zn}$ and $\mathrm{Cu}$ by kaolinite," Caspian Journal of Environmental Sciences, vol. 9, no. 2, pp. 243-255, 2011.

[46] M. R. Lasheen, N. S. Ammar, and H. S. Ibrahim, "Adsorption/desorption of $\mathrm{Cd}(\mathrm{II}), \mathrm{Cu}(\mathrm{II})$ and $\mathrm{Pb}$ (II) using chemically modified orange peel: equilibrium and kinetic studies," Solid State Sciences, vol. 14, no. 2, pp. 202-210, 2012.

[47] W. Pranata Putra, A. Kamari, S. Najiah Mohd Yusoff et al., "Biosorption of $\mathrm{Cu}(\mathrm{II}), \mathrm{Pb}(\mathrm{II})$ and $\mathrm{Zn}(\mathrm{II})$ ions from aqueous solutions using selected waste materials: Adsorption and characterisation studies," Journal of Encapsulation and Adsorption Sciences, vol. 4, no. 1, pp. 25-35, 2014.

[48] S. Yalçin, "The mechanism of heavy metal biosorption on green marine macroalga Enteromorpha linza," CLEAN-Soil, Air, Water, vol. 42, no. 3, pp. 251-259, 2014.

[49] F. B. de Souza, S. M. A. G. U. de Souza, A. A. U. de Souza et al., "Modeling of trivalent chromium speciation in binding sites of marine macroalgae Sargassum cymosum," Clean Technologies and Environmental Policy, vol. 15, no. 6, pp. 987-997, 2013.

[50] W. M. Ibrahim, "Biosorption of heavy metal ions from aqueous solution by red macroalgae," Journal of Hazardous Materials, vol. 192, no. 3, pp. 1827-1835, 2011.

[51] M. Arshadi, M. J. Amiri, and S. Mousavi, "Kinetic, equilibrium and thermodynamic investigations of $\mathrm{Ni}(\mathrm{II}), \mathrm{Cd}(\mathrm{II}), \mathrm{Cu}(\mathrm{II})$ and Co(II) adsorption on barley straw ash," Water Resources and Industry, vol. 6, pp. 1-17, 2014.

[52] M. D. Meitei and M. N. V. Prasad, "Adsorption of Cu (II), Mn (II) and Zn (II) by Spirodela polyrhiza (L.) Schleiden: equilibrium, kinetic and thermodynamic studies," Ecological Engineering, vol. 71, pp. 308-317, 2014.

[53] A. A. Al-Homaidan, H. J. Al-Houri, A. A. Al-Hazzani, G. Elgaaly, and N. M. S. Moubayed, "Biosorption of copper ions from aqueous solutions by Spirulina platensis biomass," Arabian Journal of Chemistry, vol. 7, no. 1, pp. 57-62, 2014.

[54] L. Pauling, The Nature of the Chemical Bond: An Introduction to Modern Structural Chemistry, Cornell University Press, Ithaca, NY, USA, 3rd edition, 1960.

[55] J. M. Lezcano, F. González, A. Ballester, M. L. Blázquez, J. A. Muñoz, and C. García-Balboa, "Biosorption of Cd(II), Cu(II), $\mathrm{Ni}(\mathrm{II}), \mathrm{Pb}(\mathrm{II})$ and $\mathrm{Zn}(\mathrm{II})$ using different residual biomass," Chemistry and Ecology, vol. 26, no. 1, pp. 1-17, 2010.

[56] S. Basha, Z. V. P. Murthy, and B. Jha, "Isotherm modeling for biosorption of $\mathrm{Cu}(\mathrm{ll})$ and $\mathrm{Ni}(\mathrm{ll})$ from wastewater onto brown seaweed, cystoseira Indica," AIChE Journal, vol. 54, no. 12, pp. 3291-3302, 2008.

[57] M. M. Dubinin, "The potential theory of adsorption of gases and vapors for adsorbents with energetically nonuniform surfaces," Chemical Reviews, vol. 60, no. 2, pp. 235-241, 1960.

[58] G. E. Boyd and B. A. Soldano, "Self-diffusion of cations in and through sulfonated polystyrene cation-exchange polymers," Journal of the American Chemical Society, vol. 75, no. 24, pp. 6091-6099, 1953.

[59] C. L. Massocatto, E. C. Paschoal, N. Buzinaro et al., "Preparation and evaluation of kinetics and thermodynamics studies of lead adsorption onto chemically modified banana peels," Desalination and Water Treatment, vol. 51, no. 28-30, pp. 5682-5691, 2013. 
[60] J. Plaza Cazón, M. Viera, E. Donati, and E. Guibal, "Zinc and cadmium removal by biosorption on Undaria pinnatifida in batch and continuous processes," Journal of Environmental Management, vol. 129, pp. 423-434, 2013.

[61] Q. Shi, A. Li, Z. Zhu, and B. Liu, "Adsorption of naphthalene onto a high-surface-area carbon from waste ion exchange resin," Journal of Environmental Sciences, vol. 25, no. 1, pp. 188-194, 2013.

[62] D. D. Maksin, S. O. Kljajević, M. B. Dolić et al., "Kinetic modeling of heavy metal sorption by vinyl pyridine based copolymer," Hemijska Industrija, vol. 66, no. 6, pp. 795-804, 2012.

[63] M. I. Din, M. L. Mirza, S. Ata, M. Athar, and I. U. Mohsin, "Thermodynamics of biosorption for removal of Co(II) ions by an efficient and ecofriendly biosorbent (Saccharum bengalense): kinetics and isotherm modeling," Journal of Chemistry, vol. 2013, Article ID 528542, 11 pages, 2013.

[64] N. Rajamohan, M. Rajasimman, R. Rajeshkannan, and V. Saravanan, "Equilibrium, kinetic and thermodynamic studies on the removal of Aluminum by modified Eucalyptus camaldulensis barks," Alexandria Engineering Journal, vol. 53, no. 2, pp. 409415, 2014.

[65] W. R. Leo, Techniques for Nuclear and Particle Physics Experiments: A How-to Approach, Springer, Berlin, Germany, 2nd edition, 1994.

[66] A. Bhatnagar, V. J. P. Vilar, C. Ferreira, C. M. S. Botelho, and R. A. R. Boaventura, "Optimization of nickel biosorption by chemically modified brown macroalgae (Pelvetia canaliculata)," Chemical Engineering Journal, vol. 193-194, pp. 256-266, 2012.

[67] R. B. Nessim, A. R. Bassiouny, H. R. Zaki, M. N. Moawad, and K. M. Kandeel, "Biosorption of lead and cadmium using marine algae," Chemistry and Ecology, vol. 27, no. 6, pp. 579-594, 2011. 

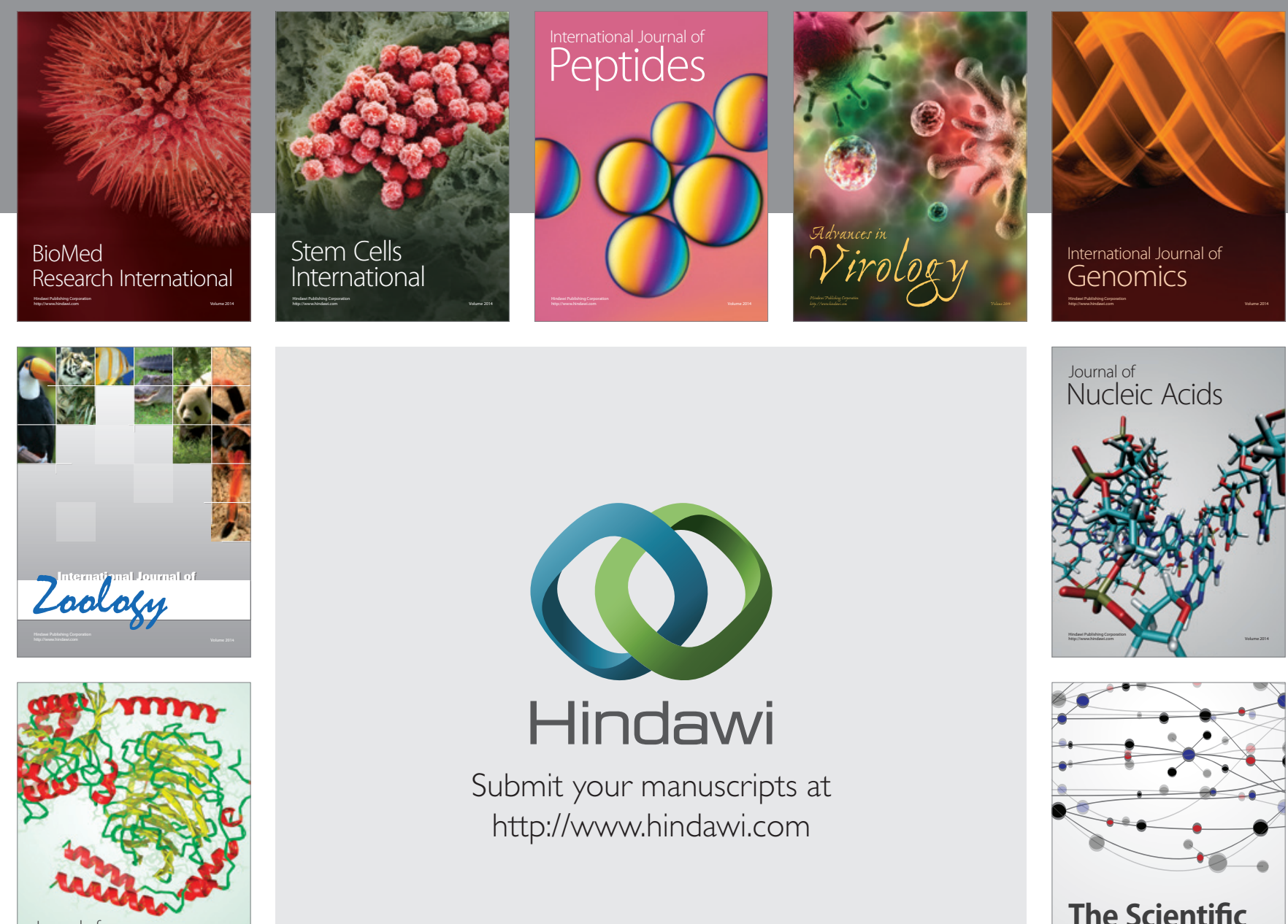

Submit your manuscripts at

http://www.hindawi.com

Journal of
Signal Transduction
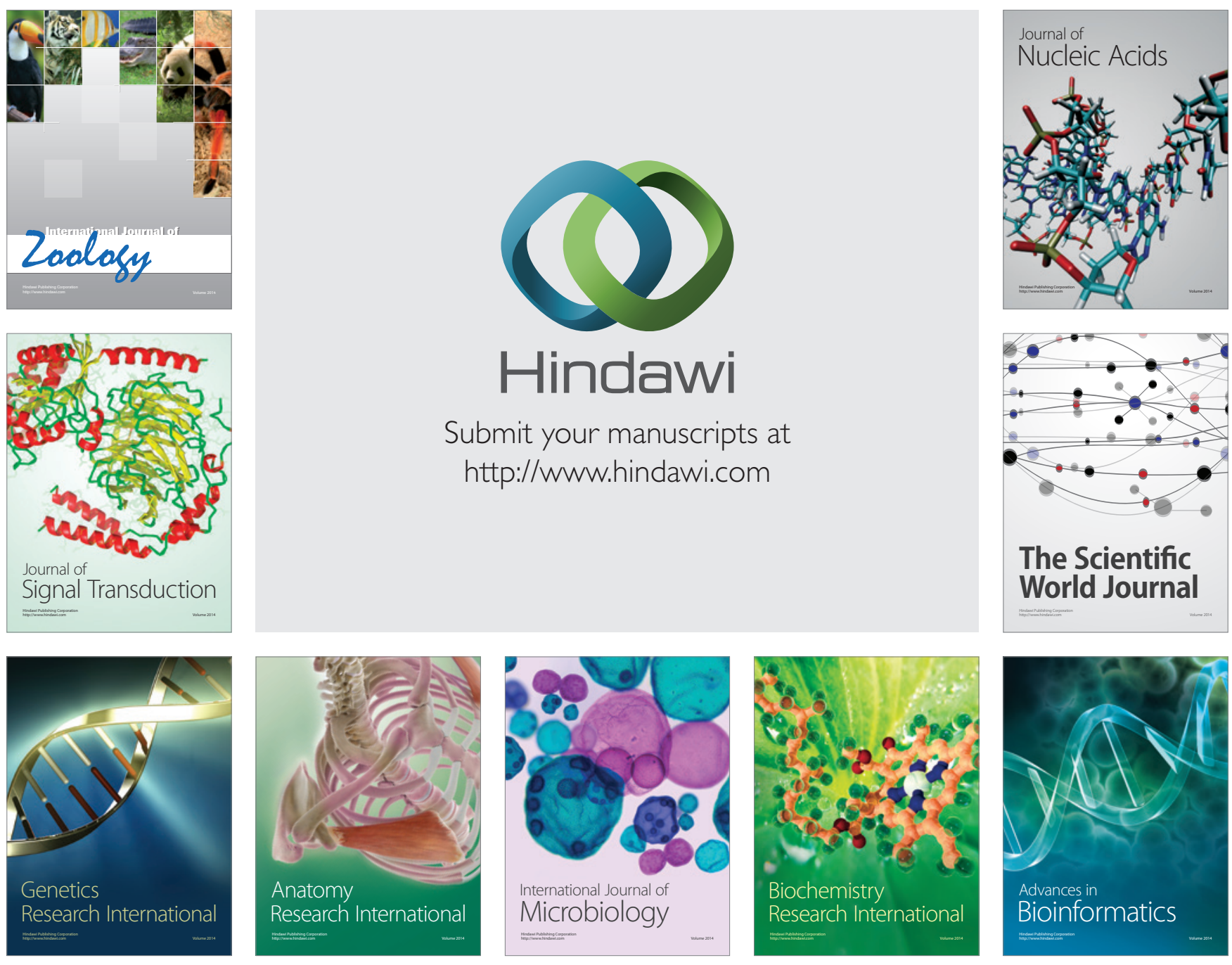

The Scientific World Journal
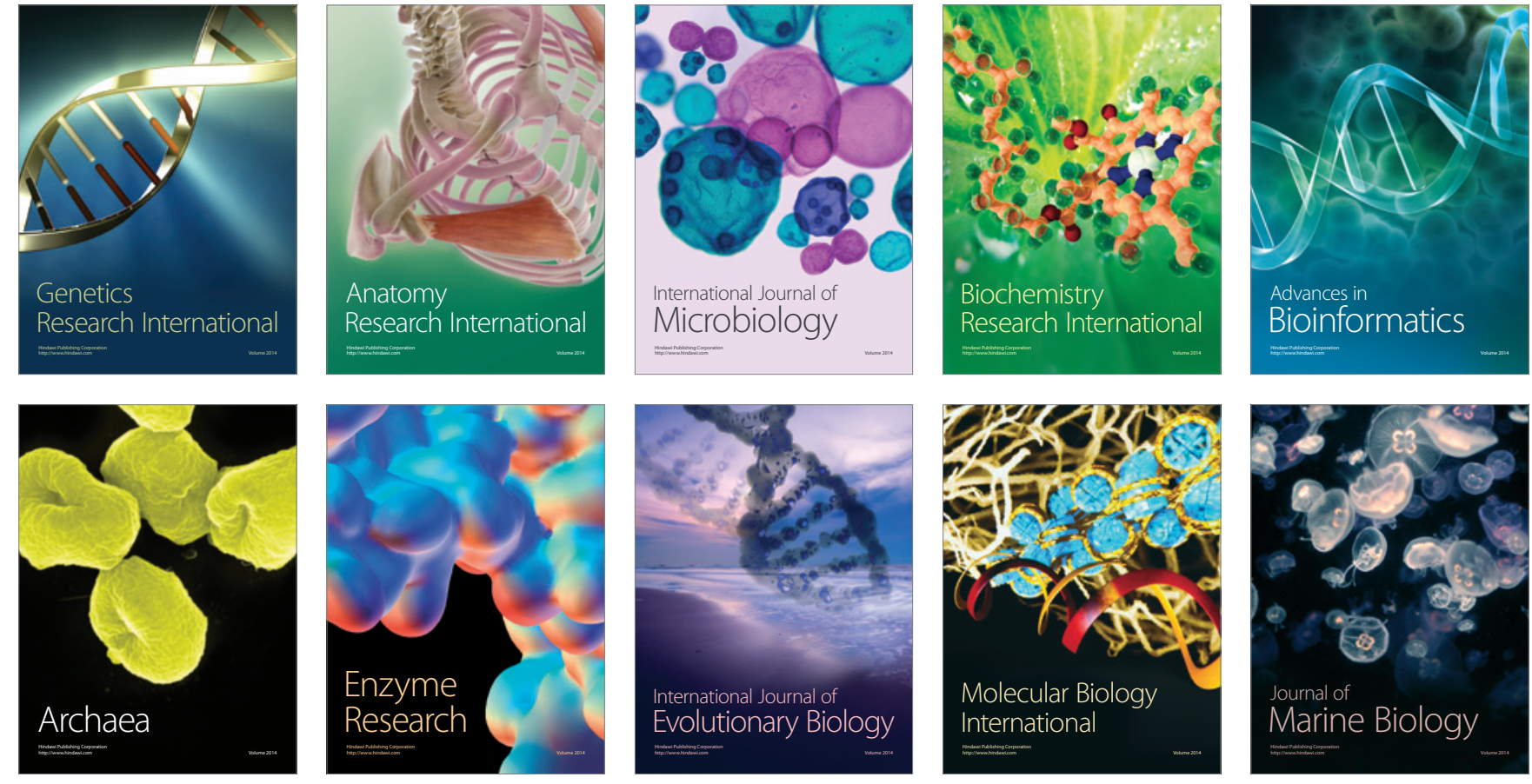